\title{
Whose Kriol is Moa Beta? Prestige and Dialects of Kriol in Belize
}

\author{
WiLliam SALMON \& JENNIFER GÓMEZ MENJÍVAR \\ University of Minnesota, Duluth ${ }^{1}$
}

\section{Introduction}

This study reports on language attitudes toward varieties of Belizean Kriol in the Central American, Caribbean country of Belize. We used a verbal-guise test with 81 participants, collecting both quantitative and qualitative data in Punta Gorda and Belize City, and we found that the variety of Kriol spoken in Belize City is perceived along several dimensions as being of greater prestige than the variety spoken in Punta Gorda. Derivative of these findings is the potentially more interesting fact that there is more than one variety of Kriol spoken in Belize in the first place - a fact which has not been previously reported in the literature. This paper will report the preferences of Kriol speakers toward two different varieties of Kriol, grouped by city and gender, on eight different personality attributes. ${ }^{2}$ We believe that these results can have potentially important consequences in Belize in terms of education and language planning, especially as the recently independent country continues to grow and develop its identity as a country with strong cultural and historical ties to both Central America and the Caribbean.

\subsection{Belizean Kriol and Languages of Belize}

Belize_-formerly British Honduras_-gained full independence from Great Britain in 1981. There is a strong influence of English as a result of this colonial history as well as from the large levels of immigration to and from the US. At the same time, however, Belize is linguistically diverse. According to the 2010 Belizean census, the country's approximately 330,000 inhabitants speak ten or more different languages (Figure 1).

\begin{tabular}{|l|l|l|l|}
\hline $\begin{array}{l}\text { Language by } \\
\text { Ethnic Group }\end{array}$ & $\begin{array}{l}\text { Number of } \\
\text { Speakers }\end{array}$ & $\begin{array}{l}\text { Language by } \\
\text { Ethnic Group }\end{array}$ & $\begin{array}{l}\text { Number of } \\
\text { Speakers }\end{array}$ \\
\hline Chinese & 2,600 & Maya Ketchi & 17,581 \\
\hline Creole & 130,467 & Maya Mopan & 10,649 \\
\hline English & 183,903 & Maya Yucatec & 2,518 \\
\hline Garifuna & 8,442 & Spanish & 165,296 \\
\hline German & 9,364 & Other & 2,729 \\
\hline
\end{tabular}

Figure 1. 2010 Census data.

\footnotetext{
${ }^{1}$ This project was funded by two grants from the Global Programs and Strategy Alliance at the University of Minnesota. Portions of this paper were presented at the 2014 meeting of the Linguistic Society of America.

${ }^{2}$ The full-length report on this project, which provides much more detailed results and discussion of 8 additional personality attributes, is currently under review as Salmon \& Gómez Menjívar (Under review).
} 
Kriol is an English-based creole, and is often considered to be the language specific to the ethnic Creole people of Belize-i.e., those of Afro-European descent. Although the data above collapses ethnic group with language, it is important to note that ethnic Creoles are not the only speakers of Kriol. The language has become something of an unofficial lingua franca across the country regardless of ethnicity, and most Belizeans speak Kriol with differing degrees of proficiency. ${ }^{3}$ According to Decker (2005:4), though ethnic Creoles are concentrated in Belize City and the Belize River Valley, "mother tongue speakers of Kriol can be found in most villages and towns throughout the country."

\section{$1.2 \quad$ Kriol}

Holm (1977:1, as reported in Decker 2005) estimates that approximately 88 percent of the vocabulary of Kriol is shared with English. But as Decker notes, this number is likely too high, as many Kriol words sound like English words but have different meanings and grammar. Thus, Kriol, like most other creoles, exists on a continuum, which ranges from a very strong identification with Standard English (the acrolect form) to a form that diverges sharply from the lexifier language (the basilect form). Decker (2005), following Young (1973) and Escure (1981), illustrates these variational points along the Kriol continuum in (1).
(1)
Basilect
Mesolect
Acrolect
Standard English
Di flai dehn mi-di bait laas nait.
Di flies dem mi bitin las nite.
Di mosquitos were bitin las nite.
The mosquitos were biting last night.

This is of course an idealization, as Kriol speakers generally move between the different points of the continuum depending on the needs of the given audience, situation, etc., much as speakers of Standard American English or any other language move between registers and styles within their own language based on the exigencies of the situation.

There is currently a strong movement underway by the Belize Kriol Project and National Kriol Council of Belize to promote Kriol. ${ }^{4}$ To this end, there is an English/Kriol dictionary (Herrera 2007) which defines many Kriol words and includes a chapter with a brief grammatical description, and there is also a Kriol translation of the New Testament, which was completed in January 2013. These projects complement a literary tradition of short fiction and poetry in Kriol, as well as a weekly newspaper column in The Reporter and a weekly radio show on Wave Radio FM 105.9. Lastly, there have been three linguistic grammars written of the language-i.e., Young (1973), Greene (1999), and Decker (2005). ${ }^{5}$

\footnotetext{
${ }^{3}$ See Escure (1997: 28-39) for a sociohistorical outline of Belizean Kriol, and suggestions as to the putative origins of Kriol in contact between Africans, Europeans, and Miskito Indians in the 18th and 19th centuries.

${ }^{4}$ Much of the work of these two organizations can be seen at the following web site: http://www.kriol.org.bz/.

${ }^{5}$ Greene (1999) is based on expatriate populations of Belizeans in New Orleans and New York City.
} 
The emerging language rights movement in Belize has focused on educational institutions. To some extent, Kriol is discussed in public primary and secondary school in Belize. The country's official educational policy as of 2008 says that students are taught to see the differences between English and Kriol, and that there should be discussion of when it is appropriate to use Kriol as opposed to English; however, it is not taught as a subject, and it is not the language of instruction for other subjects. ${ }^{6}$ Further, according to many of our participants, Kriol is not discussed in public schools at all, and they do not consider it to be a legitimate language. Many referred to Kriol as 'broken English,' and this exact phrase was one that that we heard almost everywhere by Belizeans with respect to Kriol. ${ }^{7}$

\section{$2 \quad$ Language Attitude Research on Kriol}

There appears to be no previous research at all on attitude comparisons among regional varieties of Kriol. ${ }^{8}$ There have been some impressionistic descriptions of overt and covert prestige relations of Kriol relative to English or Spanish or Garifuna, but none to our knowledge considers the question of attitude and prestige within varieties of Kriol itself, and there is no attitude work done in an empirical, systematic way. ${ }^{9}$

For example, Ravindranath (2009), writing primarily about language attitudes in the Garifuna community, suggests that Kriol is frequently seen as having greater overt prestige than Garifuna. This is a position that Escure (1997) and Bonnor (2001) take as well. Bonnor also discusses the less prestigious place of Kriol with respect to English, writing, "Creole speakers commonly defer to the superiority of speakers of foreign varieties of English, like those associated with the United States and England, and accord them greater prestige" (p.82). The result here — at least along one dimension of overt prestige — seems to be a hierarchy in which US/UK Englishes are most prestigious, followed by Kriol, and then Garifuna. Things are more complex than this, however, when covert prestige is considered and when other dimensions of

\footnotetext{
${ }^{6}$ See Belize National Standards and Curriculum Web for Language Arts (2008).

${ }^{7}$ The following is an explanation we recorded from a Belize City taxi driver on the origins and state of Belizean Kriol:

The Kriol language or Kriol dialect that we have here in Belize is actually broken English. It's English not being said in the proper form, from the days that the English were colonizing Belize and the slaves were learning the language, they said the word the way that they thought they heard it, and that became the language of the day. The slower Kriol is talk, it sound like English. But when you talk it fast, it's hard for anybody to just pick up. (male, mid-40s, ethnic Creole, native Kriol speaker).
}

\footnotetext{
${ }^{8}$ This dearth of attitude research on Belizean Kriol seems to be endemic to creole linguistics in general, as Wassink (1999:58) reports, "the body of published research concerning language attitudes held by speakers of pidgin or creole varieties is rather limited."

${ }^{9}$ Ravindranath (2009: 126-130) provides excellent summaries of claims that have been made with respect to Kriol and English, Spanish, and Garifuna. These comparisons, however, are largely impressionistic and anecdotal, which is the case with most discussions of language attitudes in Belize-including LePage (1992) and Ravindranath
} (2009). 
overt prestige are considered. We will return to this briefly below in $\S 7$; our priority in the pages that follow, though, is which varieties of Kriol show greater prestige, and in what ways.

\section{Research Questions, Design, and Methodology}

Our objective has been to examine the attitude and prestige system in place among regional varieties of Kriol. The initial phase of our fieldwork, involving informal conversations with Belizeans, revealed the rich complexity of attitudes in Belize: the pride in the language and country with the ever-accompanying warnings that Kriol was not good English. We initially encountered this seeming incongruence of attitudes in the country's largest urban area, Belize City, and we wondered if it would hold throughout the country in the rural areas as well. We thus decided to design a study that would go beyond the standard comparison of a dominant/prestige language (Standard English in this case) with the non-dominant/stigmatized language (Kriol) that is commonly found in language attitudes studies.

Based on our initial fieldwork, we hypothesized that there was significant regional variation in Kriol and that Belizeans would have different attitudes toward these varieties. ${ }^{10} \mathrm{We}$ then developed the following set of questions to guide our research.

(a) Are attitudes toward Kriol conditioned by regional variation?

(b) Are attitudes toward Kriol conditioned by urban/rural conditions?

(c) Are attitudes toward Kriol conditioned by multilingual contexts?

(d) Are there gender differences in attitudes toward regional variants?

(e) Are there regional dialects of Kriol?

With these questions, we hoped to learn how attitudes toward Kriol vary along rural and urban lines, across gender, and across regions. ${ }^{11}$ This offers the first coherent, empirically-driven study of attitudes toward varieties of Kriol.

\footnotetext{
${ }^{10}$ For example, one Belizean told us that in the northern part of the country, speakers might say Ai chravl wid mi haat which translates literally to 'I travel with my heart', but which means idiomatically that the speaker has recurring heart trouble. On the other hand, it was reported that in Belize City speakers would say instead Ai gat haat chrobl 'I have heart trouble'. It seems likely here that chravl/chrobl are simply different pronunciations of the same word: i.e. differing vowel qualities and a labiodental fricative $[\mathrm{v}]$ in the north and a bilabial stop [b] in the city. Somewhere along the way the difference in pronunciation facilitated a semantic reanalysis from chroble 'trouble' to chravl 'travel'. In this case, the reanalysis seems to make plausible sense in the context, resulting in an "eggcorn," which is a type of semantic change discussed at length on the linguistics blog Language Log as well as in numerous subsequent publications. See Liberman (2003) and Liberman \& Pullum (2006) for discussion and history of the phenomenon.

In terms of variation, the chravl/chroble distinction suggests a place to begin investigation of phonological variation in the Kriols spoken in different parts of the country. Our approach to variety in this present study was holistic, though, (Kristiansen 2009, 2011) as we were not manipulating individual markers (Labov 1963), but instead used recorded natural speech of native speakers from each of the areas in question. Isolating clear phonological markers will be a goal of future research.
} 


\subsection{Fieldwork Sites}

We chose a northern urban area, Belize City, and the southernmost sizeable town, Punta Gorda, as our fieldwork sites. Both are coastal cities, in which fishing plays an important economic and cultural role and in which various kinds of maritime tourism - fishing, scuba diving, etc. - are important to the economy. Belize City is the country's cultural center for ethnic Creoles, with a population of 61.2 percent ethnic Creole (Belize Census 2010). It is also the country's largest city, with an overall population of approximately 68,000 residents. Punta Gorda, on the other hand, has a much smaller percentage of ethnic Creoles, at 14.7 percent, and a much smaller overall population of approximately 6,000 (Belize Census 2010). Importantly, there is little contact between the two cities. This is due to the difficulty of traveling between the two locations, as well as the perception among residents of Punta Gorda that Belize City is a dangerous place due to the extensive drug and gang violence in the city. ${ }^{12}$

\subsection{Research Design}

We designed a verbal-guise test (Cooper 1975; Huygens and Vaughn 1983; Kristiansen 2009, 2011) to gauge attitudes toward the Kriol spoken in the two locations. The basic set up included recordings we made of local speakers in Belize City and Punta Gorda, as well as a modified Likert survey which was filled out by test participants in their ratings of the two recordings.

Unlike the matched-guise test (Lambert et al. 1960), which uses recordings of one speaker performing two or more different varieties, the verbal-guise test uses different speakers for each language variety. Like the matched-guise test, however, the verbal-guise conceals the identities and distinguishing locational information of the speakers from the participants. Kristiansen (2011) notes that the verbal-guise test can result in a relaxed control of voice and content effects, as compared to the matched-guise test, since there are two different speakers in the former. We tried to control for this as much as possible by recording speakers who were of the same age, sex, and ethnicity. Further, we deemed it unlikely that we would be able to find a

\footnotetext{
${ }^{11}$ Very little has been said about the role of gender in sociolinguistic attitudes in Belize-or, the rest of the creole continuum in the Caribbean, for that matter. See Winford (1991) on this fact. Escure (1991) is an exception, as she investigates the role of gender in linguistic variable choice in the village of Placencia in Belize. The present study differs from Escure's in important ways: i.e., it is concerned with attitudes toward regional dialects across the country and in urban areas rather than within the internal social dynamics of a small rural village. Winford (1991:575), discussing Escure's study, writes, "One suspects that very different pictures of sexual differentiation in language will emerge from investigation of urban communities ...."

${ }^{12}$ According to the US State Department Crime and Safety Report for Belize in 2013:
}

Due to the extremely high murder rate per capita, Belize is the sixth most violent country in the world ... In 2012, Belize recorded 145 murders, setting a new record for homicides in the country. ... The majority of the homicides occurred in Belize City. https://www.osac.gov/pages/ContentReportDetails.aspx?cid=14034. 
single speaker who controlled Kriol as spoken both in Belize City and in Punta Gorda. Thus, our test recordings were made by one individual from Belize City (Speaker 1) and a second individual from Punta Gorda (Speaker 2). Both of these speakers were ethnic Creole men in their late 30s, shared the same occupation of taxi driver, and both had lived their entire lives in Belize City and Punta Gorda, respectively. ${ }^{13}$ This allowed us to ensure that the Kriol variety they spoke reflected that spoken in our sites of interest, and so there were no concerns with authenticity as there can be with the matched-guise tests (see Garrett 2010: Chapter 4 on authenticity questions in the match-guised test).

The recordings were made on a Fostex FR-2LE digital recorder, using a Beyerdynamic M58N(C) microphone, which was fitted with a felt windscreen. The Fostex recorder has an easy digital playback function, which we used to deliver the audio recordings to each of our test subjects through a pair of Sony MDR-710 over the ear headphones. Both recordings were made outside in garden environments, and the sound quality of the recordings is very clear, with very little noise from the equipment or surrounding environment. Following the methods of Rickford (1985:148), both speakers were recorded in natural conversation with the male researcher. ${ }^{14}$ The final result was one recording in which the speaker discusses fishing, and another recording in which the speaker discusses a story his grandfather told him. ${ }^{15}$

With the editing of both recordings, there is a sense of en media res: i.e., the participants of the study hear part of a conversation that is already in progress, as if they are simply overhearing a fragment of conversation on the street. ${ }^{16}$ This manner of editing has the effect of backgrounding the actual content of what speakers were saying and thus foregrounding the voice and language of the speech itself. Further, with this type of editing, the speech to which

\footnotetext{
${ }^{13}$ We would have preferred to have a male and female recording from both areas, but this would have meant that test respondents had to listen to and rate at least four recordings rather than just two. We believed that this was not feasible in the brief, spontaneous, on-the-street type of interviews we conducted. As a result, we could not gather data on attitudes toward female speakers in this present study; however, this is certainly part of the plan for future research.

${ }^{14}$ Unlike Rickford, though, we did not allow test participants to listen to the entire recorded conversation; instead, we identified a coherent 30-second Kriol monologue that could stand alone in each recording, and we edited the recordings so that these were all that could be heard. The 30-second samples are considerably shorter than the twominute samples employed in the classic matched-guise survey of Lambert et al. (1960); however, due to our on-thestreet survey technique, it was necessary to shorten the recordings to a more flexible and workable length. Similarly, Kristiansen (2009) also employed 30-second samples in a verbal guise investigation of Danish accents in Copenhagen.

${ }^{15}$ It is often the case that matched-guise and verbal-guise tests will involve the exact same content in the recordings of both speakers; i.e. both speakers will read the same passage into the recording, etc. This is not the case in our model, as the content of the two recordings is different, but we believe uncontroversial. We are convinced by Lee (1971) that the repetition of the same content in the different recordings results in a very unnatural and artificial situation for the test participants. See also Campbell-Kibler (2013:143) on the importance of spontaneous stimuli "for a more natural evaluation task."

${ }^{16}$ See Salmon (2011) for a discussion of naturalness and manipulation of experimental conditions. Salmon is concerned with video cinematography in experimental semantics, but the idea of maximizing the extent to which conditions are natural for test participants is directly applicable in this present study.
} 
participants were exposed was more natural then, say, a recording of someone reading aloud from a written passage, as is commonly done in this kind of research.

\subsection{Methodology}

We approached potential participants on the streets of Belize City and Punta Gorda: on the campuses of the University of Belize in Belize City and Punta Gorda, at the Vernon Street fish market in Belize City, the Front Street market in Punta Gorda, as well as in various homes and businesses in both cities. ${ }^{17}$ As a result, our respondents came from a wide variety of professional and ethnic backgrounds-from lawyers to insurance salespeople to security guards to street vendors to university students-from ethnic Creole to Garifuna to Kekchi and Mopan Maya, to young and old, and male and female. Indeed, our pool of respondents was as diverse and complex as is the population of Belize itself.

Ultimately, our participant pool ( $n=81: 43$ men, 38 women) ranged in age from 20 to 60 years of age. Half of our participants were from Belize City and half were from Punta Gorda. Our participant pool was closely split between male and female in both locations. The surveys were anonymous, though we kept track of demographic information such as race, age, sex, location of interview, native language, and occupation. We used this information as a means of keeping our participant pool varied.

We initiated contact with potential test respondents by introducing ourselves and then stating that we were conducting a study on Kriol, without informing the participants what our actual interest in the language was. ${ }^{18}$ Those who opted to participate in our study first listened to Speaker 1 and then completed a five-level modified Likert survey, which included a total of 16 personality attributes for participants to rate. Each survey was printed on its own sheet of paper and attached to a clipboard, which the participants held as they filled out the survey. The rating sheet with Likert items that we gave to participants is reproduced below in Figure 2. Many of these attributes are standard across attitude studies such as ours, and the list we used was inspired by Loureiro-Rodriguez et al. (2012). ${ }^{19}$

\footnotetext{
${ }^{17}$ We saw two possibilities for gathering the kind of data we needed: the first was to use primarily university students in the traditional classroom setting, as is commonly done in these types of study. The other possibility was the individual personal interviews in a person-on-the-street manner, which we ended up choosing. We had several reasons in mind in choosing this latter method. First, we wanted to avoid what Wolfram (2011:305) refers to as "generic populations of middle-class university students." Second, we believed it likely that status judgments would very likely be affected if surveys were done in the formal setting of the university classroom, as opposed to on the street (c.f. Creber and Giles 1983). Third, we wanted to collect both quantitative and qualitative data, and it seemed much more efficient to do this by using the Likert survey in addition to follow-up dialogue conducted on the spot with individual respondents. This kind of dialogue and data collection seems less likely in the more impersonal environment of a large classroom setting.

${ }^{18}$ See Kristiansen (2011) for more on the need of keeping intentions secret.

${ }^{19}$ Loureiro-Rodriguez et al. credit Woolard (1989) as their own inspiration. In addition to the standard questions on language attitudes surveys, we contributed the attribute violent to our survey as a means of probing current attitudes toward the Kriol spoken in Belize City, which, sadly, has a reputation throughout the country of having an extremely
} 
INSTRUCTIONS: Please rate the speaker on the following personality traits, where $1=$ not at all and $5=$ very much .

$\begin{array}{llll}\text { 1. Attractive } & 12345 & \text { 9. Intelligent } & 12345 \\ \text { 2. Educated } & 12345 & \text { 10. Modern } & 12345 \\ \text { 3. Eloquent } & 12345 & \text { 11. Phony } & 12345 \\ \text { 4. Friendly } & 12345 & \text { 12. Polite } & 12345 \\ \text { 5. Hard-working } & 12345 & \text { 13. Traditional } & 12345 \\ \text { 6. Has sense of humor } & 12345 & \text { 14. Trustworthy } & 12345 \\ \text { 7. Ignorant } & 12345 & \text { 15. Unrefined } & 12345 \\ \text { 8. Improper } & 12345 & \text { 16. Violent } & 12345\end{array}$

Figure 2. Rating sheet given to participants. ${ }^{20}$

This first survey of Speaker 1 included one open-ended question, which asked participants to indicate the origin of the speaker. This question was designed to elicit an important piece of information, i.e., whether or not participants could successfully identify the origin of the speaker on the recording. From this information we hoped to infer the extent to which variation exists in Belize and, if so, how well known the different varieties are. Once this task was completed for Speaker 1, participants were asked to listen to the recording of Speaker 2, and then follow the same survey procedure as described above.

When test participants were finished with the survey for Speaker 2, we then collected qualitative data along a few different dimensions. All of our participants were asked to indicate where they believed it was appropriate to use Kriol. In addition, half the participants were asked where it was appropriate to use English and half were asked where it was appropriate to use Spanish. These questions allowed us to discover general attitudes about English and Spanish, which will play roles in our next two studies. The last two open-ended questions provided us with information as to the linguistic background of our participants. All participants were asked to indicate the first language or dialect they learned, and they were asked to list all of the languages or dialects they spoke with any proficiency.

The interviews took 5-30 minutes, depending on how much the participants wished to add regarding the qualitative aspects of the survey. When the participant was finished with both surveys and had returned them to us, we immediately wrote any further observations or comments that arose during the process on the back of the survey form in question.

high rate of violent crime. The reputation has grown such that residents of other parts of the country avoid going to Belize City. Our interest was in whether this extremely negative reputation of the city had begun to tarnish the attitude toward the language spoken there. As our results show in $\S 6$, however, this does not seem to be the case.

${ }^{20}$ We realized after the survey was well underway that many participants seemed to have trouble understanding phony. As such, we do not consider this attribute further in the present paper. 


\section{$4 \quad$ Results}

We report the results as individual Likert items, analyzed by city and gender. Figure 3, below, presents the scores for approximately half of the individual attributes, with all participants in the study from both locations grouped together. Thus, Figure 3 combines participants from Belize City (BC) and Punta Gorda (PG) to provide an overall picture of attitudes toward the two Kriol varieties under investigation.

The results are reported in medians and modes rather than means, as data for individual Likert items does not follow a normal distribution. ${ }^{21}$ Thus, these two non-parametric measures of central tendency guard against possible skewing by outliers in the Likert ratings—a protection that would not be in place if the results were reported in means.

When all participants in the study are grouped together, there is a preference for the $\mathrm{BC}$ Kriol in almost all of the positive categories, including attractive, educated, eloquent, friendly, sense of humor, intelligent, polite, and traditional. PG Kriol is clearly preferred only in the category of hard-working. ${ }^{22}$

\begin{tabular}{|l|l|l|l|l|l|}
\hline Speaker 1 $\mathbf{( B C )}$ & Med. & Mode & Speaker 2 (PG) & Med. & Mode \\
\hline Attractive & 4 & 4 & Attractive & 3 & 3 \\
\hline Educated & 4 & 4 & Educated & 3 & 3 \\
\hline Eloquent & 4 & 4 & Eloquent & 3 & 3 \\
\hline Friendly & 5 & 5 & Friendly & 4 & 4 \\
\hline Sense of Humor & 4 & 5 & Sense of Humor & 3 & 3 \\
\hline Intelligent & 4 & 4 & Intelligent & 3 & 3 \\
\hline Polite & 4 & 4 & Polite & 3 & 3 \\
\hline Traditional & 5 & 5 & Traditional & 4 & 4 \\
\hline Hardworking & $\mathbf{3}$ & $\mathbf{3}$ & Hardworking & $\mathbf{4}$ & $\mathbf{5}$ \\
\hline
\end{tabular}

Figure 3. Combined ratings for both sites ( $\mathrm{n}=38$ women, 43 men).

\footnotetext{
${ }^{21}$ See Meek, Ozgur, \& Dunning (2007) and references therein for more on the nature of Likert data as well as for discussion of appropriate types of statistical methods.

${ }^{22}$ The negative categories-i.e., ignorant, improper, unrefined, and violent-are not reported here, as they were rated as equal in the two varieties. Further, the negative categories received low ratings in general for both varieties, suggesting that neither Kriol is stigmatized.
} 
In Figure 4, which follows below, the comparison is made by gender this time. Thus, Figure 4 lists only male test respondents from BC and PG. Here, the positive attributes of attractive, educated, eloquent, friendly, sense of humor, and traditional were rated higher for BC Kriol by both groups of men. Similar to what we have seen above, PG Kriol was rated higher in hard-working by both $\mathrm{BC}$ and $\mathrm{PG}$ men.

\begin{tabular}{|l|l|l|l|l|l|}
\hline $\begin{array}{l}\text { Speaker 1 } \\
(\mathbf{B C})\end{array}$ & $\begin{array}{l}\text { BC } \\
\text { Men }\end{array}$ & $\begin{array}{l}\text { PG } \\
\text { Men }\end{array}$ & $\begin{array}{l}\text { Speaker 2 } \\
(\mathbf{P G )}\end{array}$ & $\begin{array}{l}\text { BC } \\
\text { Men }\end{array}$ & $\begin{array}{l}\text { PG } \\
\text { Men }\end{array}$ \\
\hline Attractive & $4-4$ & $4-4$ & Attractive & $3-3$ & $3-3$ \\
\hline Educated & $4-4$ & $4-4$ & Educated & $3-3$ & $4-4$ \\
\hline Eloquent & $4-4$ & $4-4$ & Eloquent & $3-3$ & $3-3$ \\
\hline Friendly & $5-5$ & $5-5$ & Friendly & $4-5$ & $4-4$ \\
\hline $\begin{array}{l}\text { Sense of } \\
\text { Humor }\end{array}$ & $4-5$ & $5-5$ & $\begin{array}{l}\text { Sense of } \\
\text { Humor }\end{array}$ & $3-3$ & $3-3$ \\
\hline Traditional & $5-5$ & $5-5$ & Traditional & $4-4$ & $4-4$ \\
\hline Hardworking & $\mathbf{3 - 3}$ & $\mathbf{4 - 4}$ & Hardworking & $\mathbf{4 - 5}$ & $\mathbf{4 - 5}$ \\
\hline
\end{tabular}

Figure 4. $B C$ men $(n=20)$ and PG men $(n=23)$.

In the final breakdown, given in Figure 5, we see rating of the two Kriol varieties by $\mathrm{BC}$ and PG women. Here again, we see clear preference for BC Kriol in terms of attractive, friendly, and traditional. Sense of humor was rated highly by BC and PG women for BC Kriol, with BC women also rating PG Kriol highly in this quality. PG women, on the other hand, rated PG Kriol lower for sense of humor.

PG Kriol is rated higher than BC Kriol by both groups of women in terms of hardworking. The same is true for improper. This latter fact is especially interesting, and it will be addressed in detail below in $\$ 6.2$. 


\begin{tabular}{|l|l|l|l|l|l|}
\hline $\begin{array}{l}\text { Speaker } \mathbf{1} \\
(\mathbf{B C})\end{array}$ & $\begin{array}{l}\text { BC } \\
\text { Women }\end{array}$ & $\begin{array}{l}\text { PG } \\
\text { Women }\end{array}$ & $\begin{array}{l}\text { Speaker } 2 \\
(\mathbf{P G})\end{array}$ & $\begin{array}{l}\text { BC } \\
\text { Women }\end{array}$ & $\begin{array}{l}\text { PG } \\
\text { Women }\end{array}$ \\
\hline Attractive & $4-4$ & $4-4$ & Attractive & $3-2$ & $3-3$ \\
\hline Friendly & $5-5$ & $5-5$ & Friendly & $4-5$ & $4-4$ \\
\hline $\begin{array}{l}\text { Sense of } \\
\text { Humor }\end{array}$ & $4-4$ & $5-5$ & Sense of & $4-4$ & $3-3$ \\
\hline Traditional & $5-5$ & $5-5$ & Traditional & $4-4$ & $4-3$ \\
\hline Hardworking & $\mathbf{3 - 3}$ & $\mathbf{3 - 3}$ & Hardworking & $\mathbf{4 - 5}$ & $\mathbf{4 - 5}$ \\
\hline Improper & $\mathbf{2 - 1}$ & $\mathbf{1 - 1}$ & Improper & $\mathbf{3 - 3}$ & $\mathbf{3 - 3}$ \\
\hline
\end{tabular}

Figure 5. BC women ( $\mathrm{n}=21)$ and $\mathrm{PG}$ women $(\mathrm{n}=17)$.

\section{Discussion}

Our results show a strong preference for $\mathrm{BC}$ Kriol in several of the positive traits, with the negative traits also generally rated lower for BC Kriol. It should be stressed, however, that neither Kriol received high ratings for negative traits. In other words, while BC Kriol seems to be viewed more favorably in general, it is not the case that PG Kriol is stigmatized or viewed especially unfavorably. In the following sections, we will discuss what we viewed as the most significant aspects of these findings.

\subsection{Positive Traits}

BC Kriol was rated higher for several of the positive traits—especially those which would be appealing on a personal, familiar level. ${ }^{23} \mathrm{We}$ believe that there are clear reasons to expect that this would be the case, including the fact that the Kriol spoken in Belize City is more traditional than that spoken in Punta Gorda and that it comes into contact with fewer languages than is the case in Punta Gorda.

The Belize City area and the nearby villages in the Belize River valley are home to a much higher percentage of ethnic Creoles than anywhere else in the country. The Creoles claim Kriol as a native language as opposed to a second language or lingua franca as is often the case elsewhere in Belize. This area is also commonly considered to be the cultural center for the Creole people. Many of our test participants in Punta Gorda and elsewhere in our travels in the

\footnotetext{
${ }^{23} \mathrm{We}$ are referring to the following attributes as positive: attractive, educated, eloquent, friendly, hard-working, sense of humor, intelligent, polite, and trustworthy. The categories modern and traditional are not clearly positive or negative. The negative attributes are ignorant, unrefined, and violent.
} 
country made comments to the effect that if we "wanted to hear real Kriol, we needed to go to Belize City and to the villages." Belize City and the river valley are also predominantly monolingual, or bilingual with Kriol and English. This differs from other parts of the country, such as the south, west, and northern borders with Guatemala and Mexico, in which several languages_-i.e., Kriol, English, Spanish, and Mayan languages_-are spoken side by side. It makes sense then to think of the Kriol spoken in the BC area as being the more traditional vernacular variant, as it has a much higher concentration of ethnic Creoles and there is less contact with other languages. The results given in the overall rankings in Figure 3 also clearly bear this out: BC Kriol is rated as more traditional than PG Kriol, while PG Kriol is rated as more modern than BC Kriol.

The conclusions we can draw from these facts fit well with the findings of surveys of creole languages reported elsewhere in the literature, in which the vernacular rates high in solidarity and personal appeal but low in power. ${ }^{24}$ For example, Rickford (1985:156), partially quoting Reisman (1970:40) on this relation, writes, "Creole [in Antigua] violates 'English' standards of 'order, decorum, quietness, and authority', but in which people in fact 'take great joy.' " This evocative description of Antiguan Creole, its formally subjugated relationship to English, and its appeal to the personal and familiar in the Creole, is precisely what we found with respect to BC Kriol. All of the groups we surveyed rated BC Kriol high on positive characteristics such as friendly, sense of humor, polite, etc.

A curious question regards why PG Kriol is rated consistently higher in the category hard-working. Given what we have described above, with BC Kriol as the more traditional of the two variants of the language, we believe that a very likely answer to this question can be seen in an analogy with Wolfram and Schilling-Estes' (1998) description of the Ocracoke Islanders and their attitudes toward the English Brogue spoken on the island. ${ }^{25}$ This explanation also dovetails nicely with the gender patterns in Kriol attitudes, in which women show the least difference in prestige between the two variants. That is, for women, BC Kriol is more prestigious in only four categories, which is lower than we see for men, who rate the traditional BC Kriol as more prestigious in six categories. On a story similar to that of Wolfram and Schilling-Estes', this divergence by gender is to be expected. We consider this analogy in more detail in the next section.

\subsubsection{Language Attitudes on Ocracoke Island, North Carolina}

Similar to Belize, the economy of Ocracoke Island has historically depended heavily on fishing, but has more recently shifted toward a tourist-based economy. This reduction of what was traditionally the men's occupation, according to Wolfram and Schilling-Estes (1998), has ramifications for attitudes toward the traditional way of speaking versus the more contemporary

\footnotetext{
${ }^{24}$ See, for example Labov (1963), Rickford (1985:151), and the references in Rickford.

${ }^{25}$ Ocracoke Island is one of the most remote islands in the Outer Banks of North Carolina.
} 
way of speaking that has come with the influx of tourism and the much more frequent contact with other languages and dialects on the island. According to Wolfram and Shilling-Estes:

As this transformation takes place, men's ability to make a living via traditional male occupations such as fishing and crabbing is diminishing rapidly. [...] For men in blue-collar communities such as Ocracoke, it may well be that vernacular variants are more closely associated with economic power than standard variants, since men in such communities achieve economic power through physical ability and physical strength rather than the ability to verbally negotiate the established power structures of the corporate and political arena. Thus, if a man on Ocracoke wishes to display symbolic power as his real earning power declines, he will maintain or even heighten his usage of vernacular variants [...] (p.196).

The authors go on to write that women, on the other hand, have less need to accrue symbolic power, as their economic positions tend to improve with the increase of tourist-based occupations for women. Thus, men tend to see the traditional speech as an indicator of symbolic power, while the women are less inclined to do so. ${ }^{26}$

It is not difficult to see the relevance to the Belizean situation here, in which BC and PG men rated the more traditional BC Kriol as more prestigious than PG Kriol. The Belizean economy, similar to that of Ocracoke, has transitioned steadily over the last few decades from a male-dominated maritime and agricultural economy to one that embraces a significant amount of international tourism, and which provides advantageous economic opportunities for women in the process. ${ }^{27}$ We do not have quantitative data on numbers of women working in the tourism

${ }^{26}$ As Wolfram (2008: 8) writes:

Because women suffer little affront to personal identity as the traditional way of life represented by the traditional language variety recedes, women are free to relinquish the traditional dialect as they come into contact with other language varieties. In fact, women may willingly embrace nontraditional language variants ... since such variants represent the demise of traditional, oppressive gender roles and definitions on the island.

${ }^{27}$ According to the World Travel \& Tourism Council's economic impact report on Belize for 2012, approximately 33 percent of Belize's GDP is tourism-based, with 30 percent of jobs in the country also directly related to tourism. For example, the coastal town of Placencia, where much of the work on Kriol and Garifuna reported in Escure (1981, 1991, 1997) was done, is no longer the rural, isolated fishing village described by Escure. In the last two decades the population has grown dramatically as a result of tourism, and there are many foreign-owned business and hotels, including one by the famous movie director Francis Ford Coppola. For example, Ocean Home: The Luxury Coastal Lifestyle Magazine had the following to say about Placencia in May 2012:

The Placencia Peninsula, along Belize's central coastline, is the latest hotspot for Central American beachfront real estate and is home to Coppola's thatched-roof beachfront retreat, Turtle Inn. To those who've previously stumbled upon Belize's downtrodden coastal capital, Belize City, 
sector of the Belizean economy, but based on our own experience throughout the country, women have a significant presence in the hotel, restaurant, and adventure tourism business. The situations between Belize and the Ocracoke Islanders are thus quite similar, both in the evolution of their economies and the shifting attitudes of women within them. ${ }^{28}$

The fact that PG Kriol is rated higher in terms of hard-working can also be understood within this analogy. The more traditional BC Kriol ranks high in traits of personal appeal; yet, like the vernacular variant of the Ocracoke Islanders, it harkens back to a more traditional economy that has rapidly given way to a modern, tourist-based one. Like the vernacular of the Ocracoke Islanders, the traditional BC Kriol can be seen to represent a kind of symbolic powerespecially to men. Yet, this does not necessarily translate as a symbol of economic power.

In addition, Wolfram (2008: 7) describes the Ocracoke vernacular variant as being tied to the traditional islander identity. We can continue the analogy here with BC Kriol as the traditional variant in Belize and as similarly tied to Belizean identity. This is especially important at the present time, given the questions of identity that exist in Belize with the changes the country has undergone since independence in 1981, i.e., the massive emigration of Belizeans to the US and elsewhere, the massive immigration of Spanish-speaking immigrants to Belize, and the aforementioned shift from the maritime subsistence economy to the tourist-based, service economy. ${ }^{29}$ Belize is very much a country in flux, and as we describe below in more detail, Kriol (especially BC Kriol) seems more than ever to be a marker of traditional Belizean identity.

\subsection{Negative Traits}

BC Kriol is seen to be more prestigious than PG Kriol along several dimensions; however, neither Kriol was perceived as especially negative or stigmatized. Thus, negative traits improper, unrefined, and violent were ranked relatively low in all groupings. We believe there are a couple

fear not; Placencia bears no resemblance to the country's economic epicenter and will quickly replace any previous feelings of "paradise lost."

http://oceanhomemag.com/francis-ford-coppolas-belize-beauties/.

${ }^{28}$ One wonders to what extent this pattern of culture, gender, and economics generalizes across cultures. That is, in many places around the world we see economies that traditionally depended on male labor now shifting to tourist or other modern economies, in which women play a greater role and thereby accrue greater economic and personal power. In these shifting economies, then, do the displaced men consistently hold the traditional language in higher prestige in terms of Capability? For example, Mayan women in Guatemala have over the last few decades taken the lead from Mayan men in terms of economic production. What was formerly a male-dominated agricultural economy has shifted into a high-tech tourist and merchant economy dominated by women who form cooperatives and market their goods online to the rest of the world. Gómez-Menjívar (2014), for example, writes about the way contemporary Mayan women shape Mayan identity through technology and the global market place. Nowhere are the men to be seen in this, and one wonders the extent to which there would be comparable implications in terms of language attitudes and symbolic power in this and other similar such shifted economies.

${ }^{29}$ See Escure (1997) and Ravindranath (2009) on the emigration/immigration patterns in Belize in the late twentieth century. The pressure of Spanish-speaking immigrants on Belizean identity is discussed below in more detail in $\S 8.1$. 
of factors involved here, including the place of Kriol with respect to English, and the role of Kriol in constructing a Belizean identity.

Recall the quote from Bonnor (2001: 82), given above in $\S 1.3$, with respect to the place of Kriol in Belize as compared to English: "Creole speakers commonly defer to the superiority of speakers of foreign varieties of English, like those associated with the United States and England, and accord them greater prestige." In terms of overt prestige, foreign Englishes are held in higher esteem-especially in formal venues. This is precisely what we found in the qualitative part of our survey, which asked where it was appropriate to use English. As we discuss in detail below in $\S 6.1$, English was claimed by all participants to be appropriate at school, one's place of employment, and so on. In other words, it is considered to be more formal. This fits very well with the low ratings of improper and violent, and the consistent and slightly higher rating of unrefined with respect to both Kriols. Thus, whatever the internal attitudes toward regional varieties of Kriol, it is likely that they all live under the shadow of the overtly prestigious foreign Englishes. ${ }^{30}$

Another factor which undoubtedly plays a role in the low negative rankings of both Kriols has to do with the role of Kriol in fashioning a national Belizean identity. According to Ravindranath (2009:129):

[D]ue to increased immigration from Spanish-speaking Central American countries, and a consistently high rate of emigration of Creole and Garinagu to the United States. These changes, accompanied by a historical distrust of Guatemala and its long lingering claim over Belize's territory, as well as competition with Spanish-speaking immigrants for economic resources in Belize, have resulted in an increase in nationalistic feeling. As Escure and LePage point out, BC is and has been important as a marker of Belizean identity, and in the face of these pressures it has developed even further as a sign of one's true Belizean citizenship. ${ }^{31}$

\footnotetext{
${ }^{30}$ Interestingly, questions regarding the place of English played no role in our survey until the very end. Participants were only asked about English after they had already completed the Likert rankings. However, it is likely that an implicit comparison was made by participants due to the fact that the surveys themselves were conducted in English. As Creber and Giles (1983) have shown, the setting of research surveys, including formality and informality of environment, as well as language in which the research is conducted (Webster 1996), can have an effect on results in attitude studies. Thus, it is possible that the presence of American English in the survey environment evoked implicit comparisons between English and Kriol, which might not have been the case had the interviewers been native speakers of Kriol.

One participant in particular-who told us she was studying to be a teacher-commented that she was happy we were educating people in Belize about the importance of speaking good English. This seemed very odd, as the surveys, recordings, etc. focused on Kriol rather than English. It does speak to the extent to which Kriol is still in the shadow of English, though.

${ }^{31}$ Ravindranath cites Escure (unpublished), LePage (1992 [1998: 75]), and Wilk (1993) on these claims.
} 
Thus, both Kriols can be seen as slightly unrefined in an implicit comparison with foreign English, but this does not cause them at the same time to be seen as especially improper. Instead, Kriol, which is seen as a vernacular when compared to English, at the same time functions as a bond to identify and unify those who assert a Belizean identity. Or, as Voorhees and Brown put it in the 2008 Lonely Planet: Belize tourism book, "Kriol is di stikki stikki paat that holds Belize together."

\section{Discussion of Qualitative Results}

In addition to the Likert surveys, we included open-ended questions to gather overt attitudes about Kriol, English, and Spanish, as well as demographic questions with respect to native language and number of languages spoken. The goal of the attitude questions was to get a sense for the place of Kriol with respect to the official language of English, and the rapidly expanding Spanish. The question regarding Spanish was included primarily for planning our next study, so the results will not be reported here. The results of the first two questions are directly related and interwoven with one another, so those results will be discussed together in the next section.

\subsection{Where is it appropriate to use English? Where is it appropriate to use Kriol?}

Kriol holds a complex place in Belize in terms of prestige. Governor General (and linguist) Sr. Colville Young writes of the negative stigma of Kriol among Belizeans:

While this stigma is slowly being lessened by work such as that being carried out by the Belize Kriol Project and by some attention being placed on Kriol's possible judicious use in the classrooms, it will take a long time to root it out-if it is ever rooted out —and in the process there may well emerge fierce language conflicts, rivalries, and divisiveness, all of which a young nation like Belize hardly needs. (2002:12)

Young's concern was supported by the qualitative sections of our interviews, in which 100 percent of our respondents said that Kriol should be spoken on the streets and with family but that English should be spoken at school, the workplace, and in more formal settings. These uniform results reveal very strong attitudes, and they are in accord with what has been said in print elsewhere. However, there is more to the story than this. For example, we have spent a great deal of time at university campuses in Belize and in businesses and government offices in Belize, and we have overheard a great deal of Kriol being spoken in those places-it wasn't spoken to us, but it was certainly spoken to other speakers of Kriol. So, Belizeans do speak Kriol at school and in the workplace; they just do so with other speakers of Kriol.

Thus far, the situation suggests a standard sort of covert prestige relationship with English. For example, Trudgill (1972), investigating Norwich English, found that speakers 
oriented overtly to the high-prestige variety, claiming that they used it frequently. In reality, though, it turned out that they used the low-prestige variety more frequently in conversation. Thus, they were oriented to the low-prestige variety covertly. They didn't realize they were using it, and so the positive evaluation of the low-prestige variety was covert. This seems very similar to what we experience with respect to Kriol in Belize.

On the other hand, Ravindranath (2009:129) states that she believes Kriol carries an overt prestige among Belizeans. She does not carry out empirical research in support of this claim, as her interests are primarily with the Garifuna speakers in Hopkins Village. ${ }^{32}$ Her claim is rooted in the fact that there is an increasing immigration to Belize from Spanish-speaking countries, resulting in more competition for economic resources and resulting in a growing nationalistic identity and pride in Kriol as a means of distinguishing Belizeans from new immigrants.

Based on our observations in the largest urban setting, Belize City, and the southernmost town, Punta Gorda, we would agree with Ravindranath with respect to Kriol as having overt prestige, though we believe that it is a very different kind of overt prestige than English holds in the country. In our opinion, the prestige of Kriol is closer to what Dodsworth (2011:199) describes as "covert prestige with overt status." Dodsworth cites Milroy (1980:19) on this kind of status:

[I]nstead of positing a sociolinguistic continuum with a local vernacular at the bottom and a prestige dialect at the top, with linguistic movement of individuals in a generally upward direction, we may view the vernacular as a positive force: it may be in direct conflict with standardized norms, utilized as a symbol by speakers to carry powerful social meanings and so resistant to external pressures.

These ways of considering prestige, described by Dodsworth and Milroy, seem much closer to us with respect to the Kriol situation in Belize. English certainly occupies an elevated space, but this does not necessarily translate into a strong overt social prestige among Belizeans, as they frequently use Kriol amongst themselves in formal settings. On the other hand, Kriol is not the language of education and government, but it does carry a kind of social prestige as a marker of national identity and as an emerging lingua franca.

In addition to the survey, we also find evidence of "covert prestige with overt status" in advertisements and signage around the country. For example, in Punta Gorda, it is easy to find business signs that contain Kriol, such as Figure 6, which is a billboard-sized sign for a national poultry wholesaler and which contains the Kriol phrase Dis da fi wi Chikin! 'This is our chicken! 33

\footnotetext{
${ }^{32}$ Hopkins is a small Garifuna village in Stann Creek district, located centrally between Belize City and Punta Gorda.

${ }^{33}$ This is a nationwide company, which according to my language consultants, is owned by Belizean Mennonites.
} 


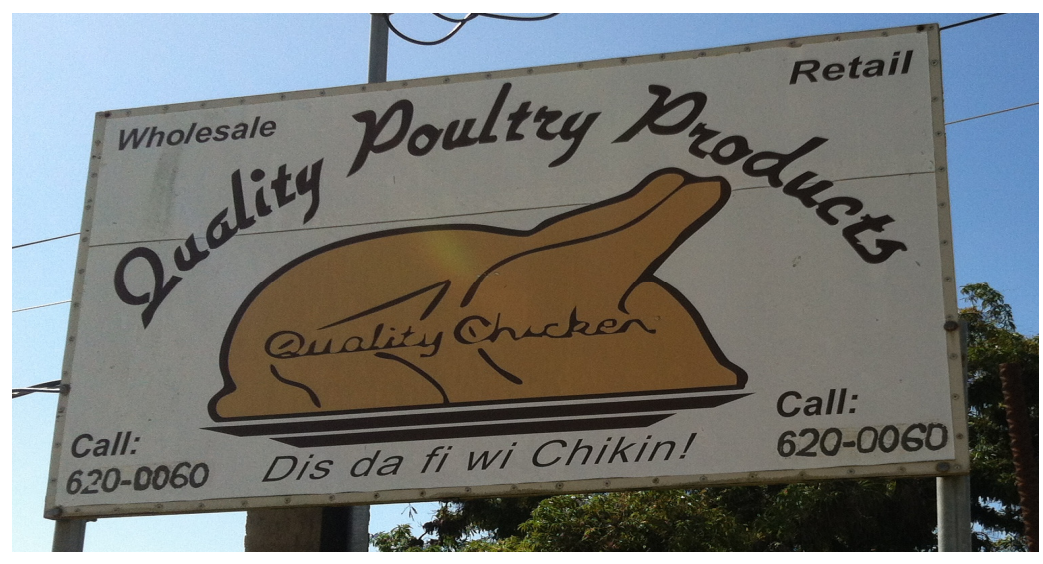

Figure 6. English advertisement with Kriol.

This sign and others like it speak to the fact that there must be an overt kind of prestige to the Kriol, but it is not the same kind of elevated space occupied by Standard English. ${ }^{34}$

\subsection{Where is this speaker from?}

In addition to the question of where English was appropriate, we asked test participants to identify the region or part of the country that they associated with the recorded speaker. ${ }^{35}$ The result here was that Belize City participants very reliably identified the speaker recorded in Belize City, and at the same time, they had more trouble locating the Punta Gorda speaker. Out of 42 participants in Belize City, 32 correctly identified the BC speaker, with only 4 correctly identifying the PG speaker. The speaker from PG was guessed to be from Jamaica, one of the Belizean Cayes, one of the lesser-populated Belizean districts, even from the US - this speaker was generally excluded as an inhabitant of Belize City. This is seen below in Figure 7. The participants from $\mathrm{PG}$, on the other hand, were able to locate the BC speaker 45 percent of the time, with most of these indicating Belize City as the speaker's origin. This suggests again that the $\mathrm{BC}$ variety of speech is at least somewhat recognizable even in southernmost Punta Gorda.

\begin{tabular}{|l|l|l|}
\hline Participants & Speaker 1 Correct & Speaker 2 Correct \\
\hline PG & $18 / 40(45 \%)$ & $7 / 40(17 \%)$ \\
\hline BC & $32 / 42(76 \%)$ & $4 / 42(9 \%)$ \\
\hline
\end{tabular}

Figure 7. Kriol dialect mapping.

\footnotetext{
${ }^{34}$ For example, LePage (1992 [1998:75]), as cited in Ravindranath (2009), writes, "the Creoles of Belize said similarly derogatory things about their language within the context of education [they] nevertheless called it Creole and identified themselves, with pride and feelings of superiority, as Creoles."

${ }^{35}$ See Preston (1989) on perceptual dialectology.
} 
Interestingly, the $\mathrm{PG}$ participants placed the $\mathrm{BC}$ speaker far more accurately than they did the speaker from their own home of Punta Gorda, whom they were only able to locate correctly 17 percent of the time. These results are surprising, but they do support the claim that there is little prestige (or notoriety) associated with the PG Kriol—a claim which is also borne out by the Likert data discussed above - and that $\mathrm{BC}$ Kriol is almost three times as recognizable to citizens of PG than their own native Kriol. These results also support the claim that there must be at least two regional varieties of Kriol in coastal Belize, a claim which has not been made elsewhere in the literature. Generally with respect to Belize, a basilect-acrolect creole continuum is assumed, but regional variation is not factored into it.

\subsection{What did you first learn to speak as a baby?}

With this question, we wanted to determine the native language of the participants. The wording with "baby" was meant to diffuse any prejudices or cultural cringe factor that might exist in case a participant viewed her native language as low prestige. We feared that in such a case participants might be inclined to indicate that their native language was other than it actually was. We also specifically did not mention the terms "language" or "dialect" here, as many Belizeans speak Kriol natively, but believe that it is a broken dialect of English. Thus, we feared the terms "language" and "dialect" could have limited or influenced the responses to this question.

We found a great deal of native language diversity in Punta Gorda with respect to native languages, with the majority of native speakers of Kriol at 18, but 7 native speakers each of the Mayan languages Mopan and Kekchi, as well as a few native speakers each of English, Spanish, and Garifuna. On the other hand, the native language count in Belize City was much less diverse, with 28 native speakers of Kriol, and 11 native English speakers. There were 2 Spanish speakers and 1 Garifuna speaker, with no native speakers of the Mayan languages (see Figure 8.1).

\begin{tabular}{|l|l|l|l|l|l|l|}
\hline Participants & Kriol & English & Spanish & Mopan & Kekchi & Garifuna \\
\hline PG & 18 & 4 & 2 & 7 & 7 & 2 \\
\hline BC & 28 & 11 & 2 & 0 & 0 & 1 \\
\hline
\end{tabular}

Figure 8.1. Native language of participants.

We suspect, however, that the report of 11 native speakers of English in Belize City is somewhat inflated. Escure (1997:37) notes that it is often the case that Belizeans do not know the difference between Kriol and English, or "may be unaware that there is any difference at all." As Kriol is an English-based creole, the distinction between the two, especially in the acrolectal range, must necessarily be quite fuzzy. When this is corrected, as in Figure 8.2 below, the landscape of native languages in the two areas seems much more realistic, with most speakers of Belize City speaking Kriol or Belizean English, but not Spanish or any of 
the Mayan languages. Conversely, Punta Gorda shows a wider linguistic range, including native speakers of Spanish and the Mayan languages.

\begin{tabular}{|l|l|l|l|l|l|}
\hline Participants & Kriol/English & Spanish & Mopan & Kekchi & Garifuna \\
\hline PG & 21 & 2 & 7 & 7 & 2 \\
\hline BC & 39 & 2 & 0 & 0 & 1 \\
\hline
\end{tabular}

Figure 8.2. Corrected native languages of participants.

The fact that Punta Gorda shows so much more diversity in reported native languages supports our claims above of PG Kriol as having much more contact with other languages than BC Kriol does. Thus, it is natural that PG Kriol would have undergone a greater degree of change and so be less traditional than $\mathrm{BC}$ Kriol—a fact that is strongly supported by the data from the Likert surveys reported in Figure 3.

\section{$7 \quad$ Conclusion}

The results of our surveys and qualitative questions invite several conclusions. Foremost among them is the fact that there must be at least two regional varieties of Kriol in Belize, as participants clearly had different attitudes toward the different speakers.

Further, our results show stronger preferences among men for BC Kriol. This preference for the more traditional variety is in line with the general notion that men are less likely to embrace linguistic change (Labov 1990, 2002).

Also noteworthy is the overall indifference for PG Kriol. PG is much more linguistically diverse, and many of our participants were bi- or trilingual, speaking some combination of Garifuna, Maya Mopan, Maya Kekchi, Spanish, or English, in addition to Kriol. This differs markedly from BC, where the majority of speakers control only Kriol and perhaps English. We believe that this polylinguistic context of PG has had an impact on language change there; conversely, the variety spoken in the monolingual BC experiences less contact, changes less, and is thus more traditional and prestigious. This fact fits well with the emerging status of Kriol as a national lingua franca and as a marker of Belizean identity: especially at a time when the newly independent country (1981) is also experiencing high levels of immigration from neighboring Spanish-speaking countries.

We know of at least one additional dimension of variation in Kriol, which appears to be generational. Our basis for believing this comes from discussions that arose during our interviews, where it was mentioned several times that younger Kriol speakers "do not speak Kriol properly" and that they are too heavily influenced by Jamaican Creole. The idea here was 
that it was much cooler to "sound Jamaican," and so young Belizeans tended to gravitate toward that way of speaking. ${ }^{36}$

Our qualitative data also supported the almost universal agreement among Belizeans to whom we spoke that "real Kriol" is found in Belize City and in the villages in the Belize River valley. This suggests that regional variation does exist and that Belizeans are aware of it. We did not investigate specific lexical or phonological differences between BC and PG; it is enough for the purposes of this study to know that the variation exists and that it is recognized by Belizeans. A goal of later research will be to isolate clear linguistic markers.

\section{Acknowledgments}

Many people have been important in the undertaking of this work. We have had fruitful discussions with Carol Klee, Mike Linn, Dennis Preston, and Ron Regal. We would also like to thank the audiences at the 2014 annual meeting of the Linguistic Society of America as well as the Berkeley Linguistics Society for much helpful feedback and suggestions; any mistakes herein are no reflection upon them. We are also extremely grateful to our Belizean consultants, who number far too many to list here. Their interest and excitement about Kriol was infectious, and it made working on this project that much more fulfilling. Special thanks to Ms. Leela Vernon, Ms. Yvette Herrera, and Ms. Silvaana Udz for very useful discussions of the language, culture, and history of Belize. Thanks also to Nigel Encalada at the National Institute of Culture and History in Belize City, and to Professor James Garber in the Department of Anthropology at Texas State University in San Marcos.

\section{References}

Belize National Standards and Curriculum Web for Language Arts, 2008. http://moe.gov.bz/rubberdoc/71d37e055d0ce2babc387f5f908beeff.pdf. (3 March, 2013.)

Belize Population and Housing Census, 2010.

http://www.statisticsbelize.org.bz/dms20uc/dynamicdata/docs/20110505004542_2.pdf. (25 October, 2013.)

Bonner, Donna. 2001. Garifuna Children's Language Shame: Ethnic Stereotypes, National Affiliation, and Transnational Immigration as Factors in Language Choice in Southern Belize. Language in Society 30: 81-96.

Campbell-Kibler, Katherine. 2013. Language Attitude Surveys. In Christine Mallinson, et al. eds., Data Collection in Sociolinguistics, pp. 142-16. New York: Routledge.

\footnotetext{
${ }^{36}$ This tension between the speech of generations in Belize seems to be ongoing, as is generally the case everywhere else between older and younger generations. For example, Greene (1999: 120) writes that in 1983 she observed older Belizeans in Belize City who were critical of the speech of younger Belizeans, who used "Michael Jacksonspeak," which was Kriol with the influence of "hip" terms such as bad to mean 'good' and dig to mean 'understand', pad 'living quarters', and huk-op 'to have sexual intercourse'.
} 
Cooper, Robert. 1975. Introduction to Language Attitudes II. International Journal of the Sociology of Language 6: 5-9.

Creber, Clare and Howard Giles. 1983. Social Context and Language Attitudes: The Role of Formality-Informality of the Setting. Language Sciences 5: 155-162.

Decker, Ken. 2005. The Song of Kriol: A Grammar of the Kriol Language of Belize. Belmopan, Belize: The National Kriol Council, House of Culture. 2nd Ed. 2009.

Dodsworth, Robin. 2011. Social Class. In Ruth Wodak, et al., eds., The SAGE Handbook of Sociolinguistics, pp. 192-207. Los Angeles: SAGE.

Escure, Genevieve. 1981. Decreolization in a Creole Continuum: Belize. In Arnold Highfield and Albert Valdman, eds., Historicity and Variation in Creole Studies, pp. 27-49. Ann Arbor: Karoma.

Escure, Genevieve. 1991. Gender Roles and Linguistic Variation in the Belizean Creole Community. In Jenny Cheshire, ed., English Around the World, pp. 595-608. Cambridge: Cambridge University Press.

Escure, Genevieve. 1997. Creole and Dialect Continua. Amsterdam: John Benjamins. Garrett, Peter. 2010. Attitudes to Language. Cambridge: Cambridge University Press. Gómez Menjívar, Jennifer. Cybertopias: Global Markets, Technology, and Mayan Identities in Guatemala. Ms., University of Minnesota.

Greene, Laurie. 1999. A Grammar of Belizean Creole. New York: Peter Lang. Herrera, Yvette, Myrna Manzanares, Silvaana Udz, Cynthia Crosbie, and Ken Decker. 2007. Kriol-Inglish Dikshineri/English-Kriol Dictionary. 4rth Printing, 2010. Belmopan, Belize: The National Kriol Council, House of Culture.

Holm, John. 1977. Miskito Words in Belizean Creole. Belizean Studies 5: 1-19.

Huygens, Ingrid and Graham Vaughn. 1983. Language Attitudes, Ethnicity, and Social Class in New Zealand. Journal of Multilingual and Multicultural Development 4: 207-223.

Kristiansen, Tore. 2009. Investigating Language in Space: Experimental Techniques. In Peter Auer and Jürgen Schmidt eds., Language and Space: Theories and Methods, pp. 52849. Berlin: Walter de Gruyter.

Kristiansen, Tore. 2011. Attitudes, Ideology, and Awareness. In Ruth Wodak, et al., eds., The SAGE Handbook of Sociolinguistics, pp. 265-278. Los Angeles: SAGE.

Labov, William. 1963. The Social Motivation of a Sound Change. Word 19: 273-309.

Labov, William. 1990. The Intersection of Sex and Social Class in the Course of Linguistic Change. Language Variation and Change 2: 205-254.

Labov, William. 2002. Driving Forces in Linguistic Change. International Conference on Korean Linguistics. http://www.ling.upenn.edu/ wlabov/Papers/DFLC.htm. (11 October, 2013.)

Lambert, Wallace, Richard Hodgson, Robert Gardner, and Samuel Fillenbaum. 1960. Evaluational Reactions to Spoken Languages. Journal of Abnormal and Social Psychology 60: 44-51.

Lee, Richard. 1971. Dialect Perception: A Critical Review and Re-evaluation. Quarterly Journal of Speech 57: 410-17. 
LePage, Robert. 1992. You Can Never Tell Where a Word Comes From: Language Contact in a Diffuse Setting. In Ernst Jahr, ed., Language Contact: Theoretical and Empirical Studies, pp. 70-101. The Hague: Mouton.

Liberman, Mark. 2003. Egg corns: folk etymology, malapropism, mondegreen??? Language Log posting. http://itre.cis.upenn.edu/ myl/languagelog/archives/000018.html. (10 November 2013)

Liberman, Mark and Geoffrey Pullum. 2006. Far From the Madding Gerund: And Other Dispatches from Language Log. Wilsonville, OR: William, James, \& Co.

Loureiro-Rodriguez, Veronica, May Boggess and Anne Goldsmith. 2012. Language Attitudes in Galicia: Using the Matched-guise Test Among High School Students. Journal of Multilingual and Multicultural Development 34: 136-153.

Meek, Gary, Ceyhun Ozgur and Kenneth Dunning. 2007. Comparison of the T vs. Wilcoxon Signed Rank Test for Likert Scale Data and Small Samples. Journal of Modern Applied Statistical Methods 6: 91-106.

Millroy, Leslie. 1980. Language and Social Networks. Oxford: Blackwell.

Preston, Dennis. 1989. Perceptual Dialectology: Nonlinguists' Views of Areal Linguistics. Dordrecht: Foris.

Ravindranath, Maya. 2009. Language Shift and the Speech Community: Sociolinguistic Change in a Garifuna Community in Belize. PhD dissertation, University of Pennsylvania.

Reisman, Karl. 1970. Cultural and Linguistic Ambiguity in a West Indian Village. In Norman Whitten and John Szwed, eds., Afro-American Anthropology, pp. 129-144. New York: The Free Press.

Rickford, John. 1985. Standard and Non-standard Language Attitudes in a Creole Continuum. Society for Caribbean Linguistics, Occasional Papers 16. St. Augustine, Trinidad. [Reprinted in Nessa Wolfson and Joan Manes, eds., Language of Inequality, pp. 145-160. The Hague: Mouton.]

Salmon, William. 2011. Determiners, Parentheticals, and Projectability: An Experimental Approach. Proceedings of Chicago Linguistic Society 47.

Salmon, William and Jennifer Gómez Menjívar. Under review. Language Variation and Dimensions of Prestige in Belizean Kriol.

Trudgill, Peter. 1972. Sex, Covert Prestige and Linguistic Change in the Urban British English of Norwich. Language in Society 1: 179-195.

Voorhees, Mara and Joshua Brown. 2008. Lonely Planet: Belize. Oakland, CA: Lonely Planet.

Wassink, Alicia. 1999. Historic Low Prestige and Seeds of Change: Attitudes Toward Jamaican Creole. Language in Society 28: 57-92.

Webster, Cynthia. 1996. Hispanic and Anglo Interviewer and Respondent Ethnicity and Gender: The Impact on Survey Response Data. Journal of Marketing Research 33: 62-72.

Wilk, Richard. 1993. Beauty and the Feast: Official and Visceral Nationalism in Belize. Ethnos 53: $1-25$. 
Winford, Donald. 1991. The Caribbean. In Jenny Cheshire, ed., English Around the World, pp. 565-584. Cambridge: Cambridge University Press.

Wolfram, Walt. 2008. When Islands Lose Dialects. Shima: The International Journal of Research into Island Cultures 2: 2-13.

Wolfram, Walt. 2011. Fieldwork Methods in Language Variation. In Ruth Wodak, et al., eds., The SAGE Handbook of Sociolinguistics, pp. 296-311. Los Angeles: SAGE.

Wolfram, Walt and Natalie Schilling-Estes. 1998. American English. Malden, MA: Blackwell.

Woolard, Kathryn Ann. 1989. Double Talk. Bilingualism and the Politics of Ethnicity in Catalonia. Stanford: Stanford University Press.

World Travel and Tourism Council. Economic Impact 2012. Belize. http://www.wttc.org/site_media/uploads/downloads/belize2012.pdf. (10 November, 2013.)

Young, Colville. 1973. Belize Creole: A Study of the Creolized English Spoken in the City of Belize in its Cultural and Social Setting. $\mathrm{PhD}$ dissertation, York University. 